\title{
PENGARUH PENGEMBANGAN KARIR DAN SELF EFFICACY TERHADAP KINERJA PEGAWAI BANK MANDIRI TARAKAN
}

\author{
THE EFFECT OF CAREER DEVELOPMENT AND SELF EFFICACY ON \\ PERFORMANCE OF BANK MANDIRI TARAKAN
}

\author{
Widyastuti Cahyaningrum ${ }^{1)}$ \\ Robert Heru Prabowo ${ }^{2)}$ \\ Universitas Borneo Tarakan \\ widyairawan77@gmail.com \\ robertheru2201@gmail.com
}

\begin{abstract}
Abstrak: Keberhasilan perusahaan sangat dipengaruhi oleh kinerja pegawaipegawai. Setiap perusahaan akan selalu berusaha untuk meningkatkan kinerja pegawai dengan harapan apa yang menjadi tujuan perusahaan akan tercapai. Tujuan penelitian ini untuk mengetahui Pengembangan Karir dan Self Efficacy berpengaruh terhadap Kinerja pegawai Bank Mandiri Tarakn. Teknik pengambilan sampel adalah sample jenuh dengan menggunakan 100 responden. Jenis penelitian ini adalah penelitian kuantitatif dengan alat kuesioner. Dalam penelitian ini menggunakan uji validilitas, uji reliabilitas, uji asumsi klasik, uji analisis linier berganda dan uji hipotesis (uji t). Hasil penelitian menunjukkan bahwa pengembangan karir berpengaruh positif terhadap kinerja, sedangkan self efficacy berpengaruh positif dan signifikan terhadap kinerja. Sebaiknya Bank Mandiri tarakan lebih meningkatkan pengembangan karir dan memunculkan self efficacy untuk membantu kinerja para pegawai Bank Mandiri Tarakan.
\end{abstract}

Kata Kunci : Kunci Pengembangan Karir, Self Efficacy dan Kinerja

Abstract: The success of the company is influenced by the performance of employees. Every company will always strive to improve the performance of their employees in order to achieve the company's goals it self. The purpose of this study is to figure out the Career Development and Self Efficacy affect the performance of Mandiri Tarakan Bank employees. The sampling technique is using a saturated sample with 100 respondents. The type of this study is quantitative research with a questionnaire. This study is using a validity test, reliability test, classic assumption test, multiple linear analysis test and hypothesis test ( $t$ test). The results showed that career development had a positive effect on performance, while self efficacy had a positive and significant effect on performance. It would be better for Mandiri Bank to improve career development and develop self efficacy to support the performance of Mandiri Tarakan

Keywords: Self Esteem, Self Efficacy and Performance 


\section{LATAR BELAKANG}

Sumber daya manusia merupakan salah satu aset terpenting bagi perusahaan dan peranan sumber daya manusia bagi perusahaan tidak hanya dilihat dari hasil produktivitas kerja tetapi juga dilihat dari kualitas kerja yang dihasilkan, dalam penelitian Yeti Indrawati (2014). Sebagaimana yang dikemukakan oleh (Hasibuan, 2014) bahwa manusia selalu beperan aktif dan dominan dalam setiap kegiatan organisasi karena manusia menjadi perencana, pelaku, dan penentu terwujudnya organisasi

Self efficacy dikemukakan oleh Bandura (dalam Jurnal Mukhid, 2009) yaitu merupakan masalah kemampuan yang diasakan individu untuk mengatasi situasi khusus sehubungan dengan penilaian atas kemampuan untuk melakukan satu tindakan yang ada hubungannya dengan tugas khusus atau situasi tertentu. Self efficacy merupakan keyakinan seseorang mengenai peluangnya untuk berhasil mencapai tugas tertentu (Kreitner \& Kinicki, 2003). Self efficacy dapat mendorong sesorang lebih bersemangat mencapai hasil optimal dalam kinerjanya, hal ini dibuktikan dengan penelitian Erez dan Judge (dalam Jurnal Yeti Indrawati, 2014 self efficacy memimpin untuk menentukan cita-cita yang menantang dan tetap bertahan dalam menghadapi kesulitan-kesulitan. Pegawai dengan self efficacy yang tinggi akan mampu mengatasi segala persoalan yang mengancam keberadaanya.

Amstrorng dan Baron (dalam Fahmi, 2013) menyatakan bahwa kinerja merupakan hasil pekerjaan yang mempunyai hubungan kuat dengan tujuan strategis organisasi, kepuasan konsumen dan memberikan kontribusi ekonomi. Adapun kinerja menurut Rivai dan Basri (2005) adalah hasil atau tingkat keberhasilan seseorang secara keseluruhan selama periode tertentu dalam melaksanakan tugas dibandingkan dengan berbagai kemungkinan, seperti standar hasil kerja, target atau sasaran atau kriteria yang telah ditentukan terlebih dahulu dan telah disepakati bersama

Bank mandiri adalah bank yang berkantor pusat di Jakarta, dan merupakan bank terbesar di Indonesia dalam hal aset, pinjaman, dan deposit, berdiri sejak 2 Oktober 1998 yang dimana bagian dari program resktrukturisasi perbankan yang dilaksanakan oleh pemerintah indonesia dikutip dari www.bankmandiri.co.id. Bank Mandiri melakukan pengembangan karir yang mempengaruhi komitmen organisasi dan kinerja pegawai, dimana pengembangan karir merupakan pendekatan formal yang dilakukan organisasi untuk menjamin orang-orang dalam organisasi mempunyai kualifikasi dan kemampuan serta pengalaman yang cocok ketika dibutuhkan. Bank Mandiri perlu mengelola karir dan mengembangkannya dengan baik supaya produktivitas pegawai tetap terjaga dan mampu mendorong karyawan untuk selalu melakukan hal yang terbaik dan menghindari frustasi kerja yang berakibat penurunan kinerja perusahaan. Pengelolaan dan pengembangan karir akan meningkatkan efektivitas dan kreativitas sumber daya manusia yang dapat menumbuhkan komitmen 
yang kuat dan meningkatkan kinerjanya dalam upaya mendukung perusahaan untuk mencapai tujuannya. Masalah lainnya pegawai Bank Mandiri memiliki kemampuan setiap individu berbeda-beda jika pegawai dituntut bekerja dalam tim, dimana setiap beban perkerjaannya juga berbeda pada setiap individunya, dan pegawai tidak semua memiliki self efficacy dalam setiap individunya dikarenakan terbiasa harus bekerja sama secara tim dan menyamakan kemampuan dalam satu pekerjaan, sedangkan pegawai harus mempertahankan kinerja yang baik. Berdasarkan uraian tersebut maka penulis tertarik untuk mengadakan penelitian guna mengetahui pengaruh pengembangan karir dan self efficacy terhadap kinerja pegawai yang penulis tuangkan dalam judul "Pengaruh Pengembangan Karir dan Self Efficacy Terhadap Kinerja Karyawan Bank Mandiri Cabang Tarakan”.

\section{PERUMUSAN MASALAH}

1. Berdasarkan latar belakang yang dikemukakan, maka rumusan masalah dalam penelitian ini adalah Apakah pengembangan karir berpengaruh terhadap kinerja pegawai Bank Mandiri Tarakan?

2. Apakah self efficacy berpengaruh terhadap kinerja pegawai Bank Mandiri Tarakan?

\section{TUJUAN PENELITIAN}

Sesuai dengan permaslahan yang telah dirumuskan, tujuan penelitian adalah sebagai berikut :
1. Untuk mengetahui pengaruh pengembangan karir terhadap kinerja pegawai Bank Mandiri tarakan?

2. Untuk mengetahui pengaruh self efficacy terhadap kinerja pegawai Bank Mandiri Tarakan?

\section{TINJAUAN PUSTAKA}

$\underline{\text { Manajemen Sumber Daya manusia }}$

Manajemen sumber daya
manusia pada dasarnya adalah
langkah-langkah perencanaan,
penarikan, seleksi, pengembangan,
pemeliharaan, dan penggunaan
sumber daya manusia untuk
mencapai tujuan individu maupun
organisasi dalam penelitian Kaseger
(2013). Pada umumnya manajemen
sumber daya manusia adalah suatu
bidang manajemen yang khusus
mempelajari hubungan dan peranan
manusia dalam organisasi
perusahaan. Manjemen sumber daya manusia adalah ilmu yang mengatur hubungan dan peranan tenaga kerja agar efektif dan efesien membantu terwujudnya tujuan perusahaan, karyawan, dan masyarakat (Hasibuan, 2014). Sedangkan menurut Armstrong (2005) menyatakan manajemen sumber daya manusia dapat diartikan sebagai pendayagunaan sumber daya manusia di dalam organisasi, yang dilakukan melalui fungsi-fungsi perencanaan sumber daya manusia, rekrutmen dan seleksi, pengembangan sumber daya manusia. Jadi manusia selalu berperan aktif dan dominan dalam 
setiap kegiatan organisasi karena manusia menjadi perencana, pelaku, dan penentu terwujudnya organisasi. Pengertian manajemen sumber daya manusia yang mungkin tepat adalah human resources mangement (manajemen sumber daya manusia), dengan sederhana pengertian sumber daya manusiaa adalah mengelola sumber daya manusia.

\section{Pengembangan Karir}

Pengembangan karir menurut Handoko (2004) menyatakan bahwa pengembangan karir adalah peningkatan pribadi yang dilakukan pegawai untuk mencapai rencana karir. Sedangkan dalam penlitian Simamora (1995), proses pengembangan karir dalam suatu pendekatan formal yang diambil perusahaan bertujuan untuk memastikan bahwa pegawai dengan kualifikasi dan pengalaman yang tepat tersedia pada saat dibutuhkan. Pengembangan karir dapat dikatakan, suatu kondisi yang menunjukan adanya peningkatan status pegawai dalam jalur karir yang telah ditetapkan. Pada dasarnya pengembangan karir berorientasi pada perkembangan perusahaan dalam menjawab tantangan bisnis pada masa yang akan datang. Setiap perusahaan harus menerima kenyataan, bahwa ekstensinya pada masa depan bergantung pada sumber daya manusia yang kompetetif karena perusahaan akan mengalami kemunduran dan akhirnya tersisih dikarenakan ketidakmampuan menghadapi pesaing. Oleh karena itu perusahaan mengharuskan perusahaan untuk melakukan pembinaan kepada pegawai yang dilakukan secara berencana dan berkelanjutan.

\section{$\underline{\text { Self Efficacy }}$}

Baron dan Byrne (2004) dalam (Amir, 2016) mengemukakan bahwa self efficacy merupakan penilaian individu terhadap kemampuan atau kompetensinya untuk melakukan tugas, mencapai suatu tujuan, dan menghasilkan sesuatu. Individu yang memiliki self efficacy yang tinggi akan mencurahkan semua usaha dan perhatiannya untuk mencapai tujuan yang telah ditentukan. Individu dengan self efficacy yang rendah ketika menghadapi situasi yang sulit akan cenderung malas berusaha dan menyukai kerja sama. Menurut Bandura (2006) dalam (Amir, 2016) self efficacy dapat ditumbuhkan dan dipelajari melalui 4 sumber yaitu kinerja atau pengalaman masa lalu, model perilaku (mengamati orang lain yang melakukan tindakan yang sama), persuasi dari orang lain dan keadaan fisilogis dan emosional.

$\underline{\text { Kinerja }}$

Kinerja merupakan istilah
yang berasal dari kata Job
Performance atau Actual
Performance (prestasi kerja atau
prestasi sesungguhnya dicapai
seseorang). Kinerja adalah hasil kerja
secara kualitas dan kuantitas yang
dicapai seorang pegawai dalam
melaksanakan tugasnya sesuai
dengan tanggung jawab yang
diberikan kepadanya
(Mangkunegara, 2005). Kinerja
merupakan hasil kerja baik kualitas
maupun kuantitas yang dihasilkan
karyawan atau perilaku nyata yang


ditampilkan sesuai dengan tanggung jawab yang diberikan kepadanya.

Berikut ini beberapa definisi yang dikemukakan oleh para ahli manajemen mengenai kinerja menurut Harsuko (2011), kinerja adalah sejauh mana seseorang telah memainkan baginya dalam melaksanakan strategi organisasi, baik dalam mencapai sasaran khusus yang berhubungan dengan peran perorangan dan atau dengan memperlihatkan kompetensi yang dinyatakan relevan bagi organisasi. Kinerja adalah suatu konsep yang multi dimensional mencakup tiga aspek yaitu sikap (attitude), kemampuan (ability) dan prestasi (accomplishment). Menurut As'ad (2003) kinerja adalah hasil yang dicapai oleh seseorang menurut ukuran yang berlaku untuk pekerjaan yang bersangkutan. Menurut Hasibuan (2006), kinerja merupakan hasil kerja yang dicapai seseorang dalam melaksanakan tugas-tugas yang dibebankan kepadanya didasarkan atas kecakapan, pengalaman, kesungguhan, serta waktu.

\section{Tinjauan Empiris}

Salah satu data pendukung yang perlu dijadikan bagian tersendiri adalah penelitian terdahulu yang relevan dengan permasalahan dan metode yang sedang dibahas pada penelitian ini. Berikut merupakan penelitian terdahulu, berupa beberapa jurnal yang relevan dengan penelitian yang dilakukan:

1. Kaseger (2013), dengan judul penelitian Pengembangan Karir dan Self Efficacy terhadap Kinerja Karyawan. Hasil penelitian yaitu terdapat pengaruh signifikan dari pengembangan karir terhadap kinerja karyawan. Sedangkan, tidak signifikan pada self efficacy. Objek yang diteliti adalah karyawan PT. Matahari Departement Store Manado Town Square dengan sampel 50 responden.

2. Bintang (2008) melakukan penelitian dengan judul pengaruh Self Efficacy terhadap kinerja Individual. Objek penelitian yang digunakan adalah pegawai Lucky Star Wedding Organizer di Semarang. Hasil penelitian menunjukan bahwa terdapat pengaruh positif dan signifikan dari Self Efficacy terhadap kinerja Individual para kru Lucky Star Wedding Organizer. Sahputra dan Hendriani (2015) melakukan penelitian, dengan judul Pengaruh Kompetensi, Komitmen dan Pengembangan karir Terhadap Karywan PT. Bank Rakyat Indonesia pada variabel pengembangan karir tidak berpengaruh terhadap kinerja karyawan.

3. Ribka dan Kawet (2014), dengan judul Pengaruh Pengembangan Karir dan Self Efficacy terhadap Kinerja Karyawan. Hasil penelitian menunjukan bahwa terdapat pengaruh positif dan signifikan variabel Pengembangan Karir dan Self efficacy terhadap Kinerja Karyawan, dengan sampel 45 orang pada objek karyawan PT. PLN (persero) area manado. Zainudin (2015), dengan judul Pengaruh Kepuasan Kerja, 
Motivasi, Komunikasi Interpersonal, Self Esteem dan Self efficacy Terhadap Kinerja Individual. Hasil penelitian menujukan bahwa variabel Self Efficacy berperngaruh positif dan signifikan pada Kinerja Individual. Veronica dkk (2013), dengan judul peran Kepuasan Kerja Self Esteem, Self Efficacy terhadap Kinerja Individual. Hasil penelitian menunjukkan bahwa terdapat pengaruh signifikan variabel Self Esteem dan Self Efficacy terhadap Kinerja Individual, objek penelitian yang dipakai adalah dosen.

\section{$\underline{\text { Hipotesis }}$}

Berdasarkan tinjauan diatas maka hipotesis yang akan diuji dalam penelitian adalah :

\section{Pengaruh Pengembangan Karir terhadap Kinerja}

Menurut penelitian yang dilakukan Kaseger (2013) menunjukan bahwa pengembangan karir siginifikan terhadap kinerja karyawan. Fauziah et al, (2016) melakukan penelitian menunjukan bahwa variabel pengembangan karir berpengaruh positif terhadap kinerja karyawan. Menurut Permatasari (2006) penelitian yang dilakukan variabel pengembangan karir berpengaruh postif dan signifikan terhadap kinerja karyawan. Bedasarkan penelitian yang dilakukan Sendow et al, (2015) pengembangan karir memiliki pengaruh positif dan signifikan terhadap kinerja karyawan. Dari beberapa penelitian diatas maka penulis menarik satu hipotesis berikut:

$H_{1}$ : Pengembangan Karir berpengaruh positif terhadap Kinerja.

\section{Pengaruh Self Efficacy terhadap Kinerja}

Menurut penelitian yang dilakukan Veronica, et al (2013) menunjukan bahwa Self efficacy memiliki pengaruh yang positif terhadap kinerja. Fauziah, et al (2016) melakukan penelitian menunjukan bahwa variabel pengembangan karir berpengaruh positif terhadap kinerja karyawan. Bedasarkan. Menurut Ribka dan Kawet (2014) variabel self efficacy berpengaruh berpengaruh secara positif terhadap kinerja karyawan. Zainudin (2015) dalam hasil penelitian menujukan bahwa variabel Self Efficacy berperngaruh positif dan signifikan pada Kinerja Individual. Dari beberapa penelitian diatas maka penulis menarik satu hipotesis sebagai berikut:

\section{$\mathrm{H}_{2}$ : Self Efficacy berpengaru positif terhadap Kinerja}

\section{Kerangka Penelitian}

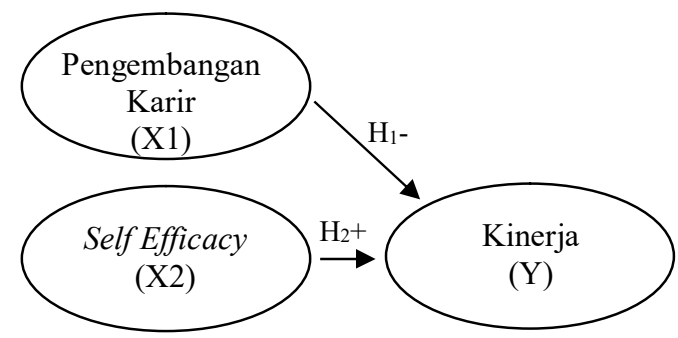




\section{METODOLOGI PENELITIAN}

Penelitian ini menggunakan pendekatan kuantitatif dan mentode survei. Metode survey digunakan untuk yang alamiah (bukan buatan), peneliti melakukan perlakukan dan pengumplan data, yaitu dengan mendengarkan atau membagikan kuesioner. Dalam penelitian ini, penulis menggunakan metodologi ilmiah yang digunakan untuk mendapatkan data yang valid dengan tujuan untuk menemukan, membuktikan dan mengembangkan suatu pengetahuan sehingga pada gilirannya dapat digunakan untuk memahami dan mengantisipasi masalah dalam bidang tertentu (Sugiyono, 2017).

Populasi yang digunakan dalam penelitian ini adalah pegawai bank mandiri cabang Tarakan dan tidak membedakan jenis kelamin. Sampel adalah bagian jumlah dan karakteristik yang dimiliki populasi. Responden dipilih menggunakan Teknik sampel jenuh. Teknik sampel jenuh adalah teknik penentuan sampel bila semua anggota populasi digunakan sebagai sampel. Dalam penelitian ini jumlah yang sampel yang digunakan adalah100 pegawai Bank Mandiri Tarakan.

Uji Validitas Uji validitas menurut Arikunto (2006), validitas mengambarkan bahwa pertanyaan yang digunakan mampu untuk mengungkapkan sesuatu yang akan diukur (valid). Uji validitas digunakan untuk mengukur sah atau tidaknya suatu kuesioner. Suatu kuesioner dikatakan valid jika pada kuesioner mampu mengungkapkan sesuatu yang akan diukur oleh kuesioner tersebut. Pengujian validitas ini mengunakan Pearson Correlation yaitu dengan cara menghitung korelasi antara nilai yang diperoleh dari pertanyaanpertanyaan. Suatu pertanyaan dikatakan valid jika tingkat signifikansinya berada dibawah 0,05 (Ghozali, 2011).

Hasil Uji Validitas Pengembangn Karir

\begin{tabular}{|c|c|c|c|c|}
\hline $\begin{array}{c}\text { No } \\
\text {. }\end{array}$ & $\begin{array}{c}\text { Butira } \\
\text { n } \\
\text { Dalam } \\
\text { Kuesio } \\
\text { ner }\end{array}$ & $\begin{array}{c}\text { Nilai } \\
\text { Korelasi } \\
\text { Pearson } \\
\text { SPSS }\end{array}$ & $\begin{array}{c}\text { Nilai } \\
\text { Korelasi } \\
\text { Yang } \\
\text { Dipersy } \\
\text { aratkan }\end{array}$ & $\begin{array}{c}\text { Keteranga } \\
\text { n }\end{array}$ \\
\hline 1. & PK1 & 0,803 & \multirow[t]{6}{*}{0,1654} & VALID \\
\hline 2. & PK2 & 0,778 & & VALID \\
\hline 3. & PK3 & 0,764 & & VALID \\
\hline 4. & PK4 & 0,712 & & VALID \\
\hline 5. & PK5 & 0,734 & & VALID \\
\hline 6. & PK6 & 0742 & & VALID \\
\hline
\end{tabular}

Sumber : Data diolah, 2019

Berdasarkan hasil uji validitas variable Pengembangan Karir terhadap masing-masing indikator pada tabel 4.6 menunjukkan nilai korelasi pearson diatas nilai korelasi yang dipersyaratkan, yaitu $>0,1654$ sehingga semua item dikatakan valid dan dapat diproses dalam pengujian selanjutnya.

\begin{tabular}{|c|c|c|c|c|}
\hline \\
\hline No. & $\begin{array}{c}\text { Butira } \\
\text { n } \\
\text { Dalam } \\
\text { Kuesio } \\
\text { ner }\end{array}$ & $\begin{array}{c}\text { Nilai } \\
\text { Korel } \\
\text { asi } \\
\text { Pears } \\
\text { on } \\
\text { SPSS }\end{array}$ & $\begin{array}{c}\text { Nilai } \\
\text { Korelasi } \\
\text { Yang } \\
\text { Dipersyarat } \\
\text { kan }\end{array}$ & $\begin{array}{c}\text { Keterang } \\
\text { an }\end{array}$ \\
\hline 1. & SE 1 & 0,947 & 0,1654 & VALID \\
\hline 2. & SE 2 & 0,951 & & VALID \\
\hline 3. & SE 3 & 0,921 & & VALID \\
\hline
\end{tabular}

Berdasarkan hasil uji validitas variable Self Efficaccy terhadap masing-masing indikator pada 
lampiran tabel 4.7 menunjukkan bahwa terdapat indikator yang dipersyaratkan, yaitu $>0,1654$, sehingga semua item dikatakan valid dan dapat diproses dalam pengujian selanjutnya.

\begin{tabular}{|c|c|c|c|c|}
\hline \multicolumn{5}{|c|}{ asil Uji Validitas Kinerja } \\
\hline No. & $\begin{array}{c}\text { Butir } \\
\text { an } \\
\text { Dala } \\
\text { m } \\
\text { Kuesi } \\
\text { oner }\end{array}$ & $\begin{array}{c}\text { Nilai } \\
\text { Korel } \\
\text { asi } \\
\text { Pearso } \\
\text { n } \\
\text { SPSS }\end{array}$ & $\begin{array}{c}\text { Nilai } \\
\text { Korelasi } \\
\text { Yang } \\
\text { Dipersyarat } \\
\text { kan }\end{array}$ & $\begin{array}{c}\text { Keterang } \\
\text { an }\end{array}$ \\
\hline 1. & K1 & 0,638 & 0,1654 & VALID \\
\hline 2. & $\mathrm{~K} 2$ & 0,715 & & VALID \\
\hline 3. & K3 & 0,730 & & VALID \\
\hline 4. & K4 & 0,672 & & VALID \\
\hline 5. & K5 & 0,529 & & VALID \\
\hline
\end{tabular}

Berdasarkan hasil uji validitas Kinerja terhadap masing-masing indikator pada lampiran tabel 4.8 menunjukkan bahwa terdapat indikator yang dipersyaratkan, yaitu $>0,1654$, sehingga semua item dikatakan valid dan dapat diproses dalam pengujian selanjutnya.

Uji Reliabilitas Uji reliabilitas merupakan alat ukur suatu kestabilan dan konsistensi responden dalam menjawab hal yang berkaitan dengan konstruk-konstruk pertanyaan yang merupakan dimensi suatu variabel dan disusun dalam suatu bentuk kuesioner (Sujarweni, 2015). Pengukuran reliabilitas dilakukan dengan cara one shot atau pengukuran sekali saja dengan alat bantu SPSS uji statistik Cronbach Alpha $(\alpha)$. Suatu variabel dikatakan reliable jika memberikan nilai Cronbach Alpha > 0,6 (Sujarweni, 2015).

\begin{tabular}{|c|c|c|}
\hline \multicolumn{3}{|c|}{ Hasil Reliabilitas } \\
\hline Variabel & $\begin{array}{c}\text { Cronbach's } \\
\text { Alpha }\end{array}$ & Keterangan \\
\hline $\begin{array}{c}\text { Pengembangan } \\
\text { karir }\end{array}$ & 0,849 & Reliable \\
\hline Self Efficacy & 0,933 & Reliable \\
\hline Kinerja & 0,667 & Reliable \\
Pegawai & & \\
\hline Sumber : Data diolah, 2019 \\
Dari \\
tabel \\
menunjukkan
\end{tabular}

Cronbach's Alpha untuk variabel pengembangan karir $>0,60$ yaitu 0,849 yang menunjukkan bahwa dapat diterimanya derajat reliabilitas. Maka dapat diartikan intrumen pada variabel pengembangan karir memiliki kestabilan dan konsisten responden dalam menjawab hal yang berkaitan dengan pernyataan yang merupakan dimensi suatu variabel yang disusun dalam suatu bentuk kuesioner.

Dari tabel diatas menunjukkanbahwa nilai Cronbach's Alpha untuk variabel self efficacy > 0,60 yaitu 0,933 yang menunjukkan bahwa dapat diterimanya derajat reliabilitas. Maka dapat diartikan instrumen pada variabel self efficacy memiliki kestabilan dan konsisten responden dalam menjawab hal yang berkaitan dengan pernyataan yang merupakan dimensi suatu variabel yang disusun dalam suatu bentuk kuesioner.

Dari tabel diatas menunjukkan bahwa nilai Cronbach's Alpha untuk variabel kinerja pegawai $>0,60$ yaitu 0,667 yang menunjukkan bahwa dapat diterimanya derajat reliabilitas. Maka dapat diartikan instrumen pada variabel kinerja pegawai memiliki kestabilan dan konsisten responden dalam menjawab hal yang berkaitan dengan pernyataan yang merupakan 
dimensi suatu variabel yang disusun dalam suatu bentuk kuesioner.

\section{Analisis Regresi Linear Berganda}

Analisis ini digunakan untuk mengetahui seberapa besar pengaruh variable bebas yaitu pengembangan karir $\left(\mathrm{X}_{1}\right)$ dan self efficacy $\left(\mathrm{X}_{2}\right)$ terhadap variable terikatnya yaitu kinerja (Y). Persamaan regresi linear berganda adalah sebagai berikut (Ghozali, 2011) :

$$
\begin{aligned}
& \mathrm{Y}=\mathrm{a}+\beta_{1} \mathrm{X}_{1}+\beta_{2} \mathrm{X}_{2}+\mathrm{e} \\
& \text { Keterangan : } \\
& \mathrm{Y} \quad=\text { Kinerja } \\
& \mathrm{a} \quad=\text { Konstanta } \\
& \mathrm{X}_{1} \quad=\text { PengembanganKarir } \\
& \mathrm{X}_{2} \quad=\text { Self Efficacy } \\
& \beta_{1,} \beta_{2}=\text { Koefisien Regresi } \\
& \mathrm{e} \quad=\text { Error }
\end{aligned}
$$

\section{Uji Hipotesis (Uji - t)}

Menurut Ghozali (2011) uji t digunakan untuk menentukan apakah variable independen $(\mathrm{X})$ berpengaruh secara pasrial atau sendiri-sendiri terhadap variable dependen (Y). Dimana $t_{\text {hitung diperoleh dari hasil }}$ output SPSS sedangkan $t_{\text {tabel }}$ diperoleh dari nilai statistik dengan melihat nilai signifikansi (a) dan degree of freedom.

Pengujian ini dilakukan berdasarkan perbandingan nilai $t_{\text {hitung }}$

\begin{tabular}{|c|c|c|c|c|c|}
\hline \multicolumn{6}{|c|}{ Ringkasan Hasil Uji Hipotesis } \\
\hline \multirow{2}{*}{$\begin{array}{c}\text { Hubung } \\
\text { an }\end{array}$} & \multicolumn{4}{|c|}{ Efek } & \multirow[b]{2}{*}{$\begin{array}{l}\text { Keteranga } \\
\text { n }\end{array}$} \\
\hline & $\mathbf{t}_{\text {hitung }}$ & $\mathbf{t}_{\text {tabel }}$ & Beta & Sig & \\
\hline $\begin{array}{c}\text { Pengemb } \\
\text { angan } \\
\text { Karir }\end{array}$ & $\begin{array}{c}1,74 \\
1\end{array}$ & \multirow{2}{*}{$\begin{array}{c}1,29 \\
0\end{array}$} & $\begin{array}{c}0,15 \\
5\end{array}$ & 0,85 & Terdukung \\
\hline $\begin{array}{c}\text { Self } \\
\text { Efficacy }\end{array}$ & $\begin{array}{c}5,08 \\
2\end{array}$ & & $\begin{array}{c}0,45 \\
2\end{array}$ & 0,00 & Terdukung \\
\hline
\end{tabular}
masing-masing koefisien regresi dengan nilai $t_{\text {tabel }}$ sesuai dengan tingkat signifikansi yang digunakan.

1. Jika $t_{\text {hitung }}>t_{\text {tabel }}$ maka hipotesis terdukung.

2. Jika $t_{\text {hitung }}<\mathrm{t}_{\text {tabel }}$ maka hipotesis tidak terdukung
Sumber : Data diolah, 2019

\section{PEMBAHASAN}

\section{Pengembangan Karir berpengaruh positif terhadap Kinerja Bank Mandiri Tarakan.}

\begin{abstract}
Ringkasan hasil uji hipotesis pertama menunjukkan bahwa hubungan tersebut memiliki nilai $t_{\text {hitung }}$ sebesar 0,1741 signifikan pada $\alpha=0,05$ (one tailed) nilai tabel 1,290 , maka dari itu nilai $t_{\text {hitung }}>t_{\text {tabel }}$ dan nilai signifikan 0,85 yang lebih besar dari 0,05 . Hal tersebut menunjukkan bahwa pengembangan karir berpengaruh positif terhadap kinerja. Dengan demikian dapat disimpulkan bahwa hipotesis 1 diterima.
\end{abstract}

Berdasarkan hasil penelitian yang dilakukan pada pegawai Bank Mandiri Tarakan, menunjukan bahwa rata-rata persepsi responden yang tertinggi, dimana pengembangan karir berpengaruh terhadap Kinerja. Penelitian ini menunjukan bahwa pengembangan karir berpengaruh positif terhadap Kinerja pada Bank Mandiri Tarakan. Semakin tinggi pengembangan karir akan berpengaruh terhadap meningkatnya kinerja. Bank Pegawai bank mandiri tarakan dengan tingkat pendidikan yang baik, usia produktif dan ratarata masa kerja 1-10 tahun yang dapat menyelesaikan target yang 
diberikan Bank Mandiri Tarakan. Bank mandiri menetapkan pengembangan karir dengan standar seperti prestasi kerja, eksposur, peluang tumbuh, kestiaan terhadap perusaahaan, supervisor, dan peluang tumbuh. Dengan pengembangan karir yang dilaksanakan yang baik. Maka bank mandiri mampu mengetahui kinerja pegawai yang dikembangkan ke tingkat yang lebih atas. Serta dapat memberi karir atau tanggung jawab lebih dengan dasar standar yang ditentukan oleh Bank Mandiri.

Hasil penelitian ini sejalan dari penelitian sebelumnya Kasegger (2013) yang menyimpulkan pengeembangan karir berdampak positif terhadap kinerja karyawan PT. Matahari Departement Store Manado Town Square.

\section{Self Efficacy berpengaruh positif dan signifikan terhadap Kinerja pegawai Bank Mandiri Tarakan.}

Berdasarkan tabel 4.13 bahwa nilai $\mathrm{t}$ hitung sebesar $5.082>\mathrm{t}$ tabel 1,741 dan tingkat signifikansi t lebih kecil $0,05 \quad$ (sig $0,00<0,05$ ). Berdasarkan hasil tersebut dapat diartikan bahwa Self Efficacy memiliki pengaruh yang positif dan signifikan terhadap kinerja pegawai. Yang artinya semakin baik rasa self efficacy disuatu perusahaan maka akan semakin baik juga kinerja dari pegawai yang ada diperusahaan tersebut, dan juga self efficacy bermakna untuk meningkatkan kinerja pegawai Bank Mandiri Tarakan. Oleh karena itu hipotesis 2 "Self Efficacy berpengaruh positif terhadap kinerja pegawai" diterima.
Berdasarkan hasil penelitian yang dilakukan pada pegawai Bank Mandiri Tarakan, menunjukan bahwa rata-rata persepsi responden yang tertinggi, dimana Self Efficacy berpengaruh terhadap Kinerja. Penelitian ini menunjukan bahwa Self Efficacy berpengaruh positif terhadap Kinerja pada Bank Mandiri Tarakan. Semakin tinggi self efficacy akan berpengaruh terhadap meningkatnya kinerja. Hal ini dibuktikan dengan jawaban responden pada variabel Self Efficacy nilai rata-rata tertinggi adalah butir peryataan "Saya mampu mengejerjakan tugas dalam situasi tertentu". Kemudian dalam hubungan self efficacy dengan kinerja pegawai, pegawai mampu untuk bekerja lebih baik dengan kemampuannya dalam melakukan kinerja. Pegawai Bank Mandiri Tarakan dengan tingkat pendidikan yang baik, usia produktif dan rata-rata masa kerja 1-10 tahun yang dapat menyelesaikan target yang diberikan Bank Mandiri Tarakan. Maka setiap pegawai dengan usia mayoritas bekerja 1-10 telah memiliki pengalaman untuk mengatasi tugas yang telah diberikan. Hal ini sesuai dengan 3 indikator self efficacy, yaitu tingkat (level), kekuatan (strength), dan generalisasi (geneality), dimana pegawai mampu menyelesaikan tugas yang diberikan dengan keyakinan mengenai kemampuan dalam situasi yang bervariasi.

Hasil penelitian sejalan dengan penelitian sebelumnya Bintang (2008) yang menyimpulkan bahwa Self Efficacy berpengaruh positif dan signifikan terhadap terhadap kinerja Individual para kru Lucky Star Wedding Organizer. 


\section{KESIMPULAN}

Berdasarkan hasil penelitian dan pembahasan hasil pengujian hipotesis dan pertanyaan-pertanyaan penelitian maka dapat diambil kesimpulann sebagai berikut :

1. Pengembangan karir berpengaruh positif terhadap kinerja pegawai. Maka dari itu semakin baik pengembangan di perusahaan itu akan berpengaruh semakin baik juga kinerja pegawai dari perusahaan itu. Dengan demikian pengembangan yang diterapkan oleh Bank Mandiri dengan mayoritas di usia produktif sehingga dapat menghasilkan kinerja pergawai yang maksimal.

2. Self eficacy berpengaruh positif dan signifikan terhadap kinerja pegawai. Maka dari itu semakin self effcacy pegawai disuatu perusahaan maka akan berpengaruh semakin baik juga kinerja pegawai dari perusahaan itu. Artinya dengan mayoritas pegawai Bank Mandiri Tarakan yang didominasi oleh usia produktif, dengan rata-rata latar belakang pendidikan SMA/SMK/Sederajat, usia yang produktif dan masa kerja yang cukup prgawai memiliki self efficacy yang baik sehingga pegawai menghasilkan kinerja yang maksimal.

\section{DAFTAR PUSTAKA}

A. A Anwar Prabu Mangkunegara. 2005. Sumber Daya Manusia Perusahaan. Bandung: Remaja Rosdakarya
Bintang, Gabriel. 2008. Pengaruh Self Efficacy Terhadap Kinerja Individual Pada Lucky Star Wedding Organizer. Other Thesis

Cahyono, Budhi dan Suharto. 2005. Pengaruh Budaya Organisasi, Kepemimpinan dan Motivasi Kerja Terhadap Kinerja Sumber Daya Manusia Di Sekretariat DPRD Propinsi Jawa Tengah. Jurnal JRBI, (1)

Ghozali, Imam. 2011. Aplikasi Analisis Multivariate Dengan Program SPSS. Semarang: Badan Penerbit Universitas Diponegoro

Gomes, Faustino Cardoso. 2003. Manajemen Sumber Daya Manusia. Yogyakarta: Andi

Handoko, Hani T. 2004. Manajemen Sumber Daya Manusia. Yogyakarta: BPFE

Hasibuan, Malayu. S.P. 2006. Manajemen Sumber Daya Manusia: Edisi Revisi. Jakarta: Bumi Aksara Https://www.bankmandiri.co.id Indrawati, Y. 2014. Pengaruh Self Efficacy Dan Kepuasan Kerja Terhadap Kinerja Karyawan (Studi Kasus Perawat RS Siloam Manado). Jurnal Riset Bisnis dan Manajemen, 4 (2)

Kreitner, Robert, and Kinicki, Angelo. 2003. Perilaku Organisasi, Dalam:Early Suandy (Penterjemah). Jakarta: Salemba Empat

Melinda, T. 2004. Budaya

Perusahaan dan Persepsi

Pengembangan Karir Pada

Karyawan Yang Bekerja Di PT

Telekomunikasi Indonesia. Jurnal Psikologi, 1

Prasetya, V. 2013. Peran Kepuasan Kerja, Self Esteem, Self Efficacy Terhadap 
Kinerja Individual. Jurnal Riset

Manajemen dan Akuntansi, 1 (1)

Rahayu, Angga S., 2015.

Pengaruh Kompetensi, Komitmen

Dan Pengembangan

Karir Terhadap Kinerja Karyawan

Pt. Bank Rakyat Indonesia (Persero)

Kantor Wilayah Pekanbaru. Jurnal

Tepak Manajemen Bisnis, 2 (8)

Regina, G. Kaseger. 2013.

Pengembangan Karir Dan Self-

Efficacy Terhadap Kinerja Karyawan

Pada Pt. Matahari Department Store

Manado Town Square. Jurnal EMBA

Ribka, Rinna R., 2014.

Pengaruh Perencanaan Karir Dan

Self Efficacy Terhadap Kinerja

Karyawan Pada PT. Pln (Persero)

Area Manado. Jurnal EMBA, 4 (2)

Rivai, Veithzal, dan Ella

Djauhari Sagala. 2013. Manajemen

Sumber Daya Manusia Untuk

Perusahaan. Jakarta: Rajawali Pers

Saksono. 2003.

Pengembangan Karier dan Staf.

Yogyakarta: Balai Pustaka

Simamora, H. 1995.

Manajemen Sumber Daya Manusia

Edisi III. Yogyakarta: Sekolah

Tinggi Ilmu Ekonomi YKPN

Sujarweni, V Wiratna. 2015Metodologi Penelitian Bisnis \&

Ekonomi. Yogyakarta:

PUSTAKABARUPRESS.

Sugiyono. 2017. Metode

Penelitian Kuantitatif, Kualitatif, dan

$R \& D$. Bandung: Alfabeta

Zainuddin. 2015. Pengaruh Kepuasan Kerja, Motivasi, Komunikasi Interpersonal, Self Esteem dan Self Efficacy Terhadap Kinerja Individual (Studi Empiris pada Distributor Tiens Unicore di Makassar). El-Muhasaba, 2 (6) 
